\title{
The Uniqueness of Influencer Marketing in the Indonesian Muslim Fashion Industry on Digital Marketing Communication Era
}

\author{
Melly Maulin Purwaningwulan \\ Departement of Communication \\ Science \\ Universitas Komputer Indonesia \\ Bandung, Indonesia \\ melly16002@mail.ac.id \\ Susanne Dida \\ Faculty of Communication Science \\ Universitas Padjadjaran \\ Bandung, Indonesia \\ susanne.dida@unpad.ac.id
}

\author{
Asep Suryana \\ Faculty of Communication Science \\ Universitas Padjadjaran \\ Bandung Indonesia \\ a.suryana@unpad.ac.id
}

\author{
Uud Wahyudin \\ Faculty of Communication Science \\ Universitas Padjadjaran \\ Bandung Indonesia \\ uud.wahyudin@unpad.ac.id
}

\begin{abstract}
Influencer marketing is the one who managed to attract the attention of people on digital platforms, such as celebgram and vlogger. The advantages of social media that enable direct interaction with consumers has lead to the use of influencer marketing as a trend to promote the brand. One industry that actively uses influencer marketing is Indonesia's Muslim fashion industry. Research aimed to analyze and find solutions about the effectiveness, creativity process, uniqueness, and selectivity of influencer marketing in promoting the brand in the Indonesia's Muslim fashion industry. The research method used is case study. Case study research is a study that examines the contemporary phenomenon as a whole and comprehensive, this study in accordance with the focus of research on influencer marketing as a present phenomenon. The results obtained that influencer marketing trusted more engage on consumers in promoting the product, the process of creativity in creating ideas and promotional content based on their identity so there were a different approaches, the uniqueness of influencer marketing in Muslim fashion required extra selectivity because they have to build beautiful Islamic branding.
\end{abstract}

Keywords- Influencer Marketing, Muslim Fashion, Digital Marketing Communication

\section{INTRODUCTION}

Muslim fashion industry grows rapidly. In fact, Indonesia is hopeful to be the cornerstone of world's Muslim fashion industry by 2025 . The main driving factor for this rapid growth is the surge of middle class segment which reaches $50 \%$ and $85 \%$ of those are Muslims. Mathematically, for example, Indonesia's population is around 263,000,000, thus, the Middle Class Economy in Indonesia as of December 2017 has reached approximately $138,000,000$ people. (Interview with Rachman Ridhatullah, 24 ${ }^{\text {th }}$ July 2018).

Other factors are the rise of communities that directly or indirectly influence women to wear hijab, such as Hijaber Community, Peduli Hijab, Hijab Mom Community, Ladies Pemuda Hijrah and many others and the increasing trend of celebrities that start to wear hijab, such as Peggy Melati
Sukma, Risti Tagor, Venita Arie, Dewi Sandra and other celebrities. (Interview with Demaz Hadi, $9^{\text {th }}$ July 2018)

The number of Muslim fashion events and trends in the use of Muslim clothing including hijab as part of the main fashion items have also contributed to the growth of Muslim fashion in Indonesia.

The magnitude of the potential of the Muslim fashion market in Indonesia raises competition. Competitions not only come from Indonesian businesspeople but also from other countries such as Malaysia or global brands such as Dolce \& Gabbana who has launched abaya and hijab clothing. Zara, Louis Vuitton, Gucci and H\&M has also begun to enter the Muslim fashion industry. Competitions are getting fierce, where more producers are involved in meeting consumers' needs and demands, causing companies to make customer satisfaction as their number one priority.[1]

Business competition drives companies to find ways as to how to penetrate further into the market so that people are more convinced to make purchases. In today's digital era, people are required to be able to keep up with the changes that every so often occur quickly. One of the significant changes in the digital era and technology as it is now being the emergence of mobile applications that become everyday needs of consumers.

These habits eventually change the behavior of advertisers in marketing their products. One real example is the emergence of e-commerce, which makes shopping activities easier and more practical without having to leave. The massive influence of the Internet and social media contribute in public's buying decision process. This causes a change in the way companies promote products, namely by utilizing digital platforms.

The presence of various social media platforms continues to evolve into one of the new strategies in the marketing world that is better known as digital marketing. While in the past brand manufacturers only promoted their marketing activities in a conventional way, marketers are now obliged 
to change marketing patterns and tactics so as not to be crushed by the times and able to compete in the free market with their competitors. Thousands of marketers have turned to the internet as a prospective medium to promote their brands and carry out sales. [2]

In addition to its vast accessibility, Internet is known to be an interactive media that is perfect for public targeting. [3]

This condition, in business context, represents a strategy that illustrates business direction that follows a given environment which becomes guidelines for allocating resources and effort of an organization. [4]

The trend of using influencers to promote products also occur in the Indonesian Muslim fashion industry. Influencer marketing is a marketing method by designating people who have an influence on the community and are considered a suitable target of promotion of the brand. Another definition of influencer marketing is a marketing strategy that focuses on targeting industry leaders or specific figures to promote brand messages and awareness to certain consumer markets. Therefore, influencer marketing is an advertising or marketing method that uses influencers in social media such as Instagram, YouTube, Blog, Twitter and others. The definition of influencer is often biased by the definition of popularity. While in fact, influencers are not limited to people who has millions of followers on social media. Influencers are people who have reputation, knowledge, and skills on particular field or area.

The purpose of using influencers, among others, is to change the way consumers think or behave, because influencers can create trends and encourage their followers to buy the products they promote. In other words, an influencer is a person who has capacity to influence people's perceptions or make them do different things. In the context of influencer marketing, an influencer is a person who helps other people to buy products or services.

The following presents studies related to marketing influencers and digital marketing communication.

Nazlim Tüzel Uraltaş with New Digital Marketing Actors: Private Shopping Clubs and Their Advertising Practices. The results of the study explained that today's business world is characterized by intense competition, advertisers and marketers who take advantage of the internet, social media and digital marketing to lure consumers. In this context, consumer buying behavior also changes in line with technological development and economic capability. The conclusion of this study is that digital marketing shows parallel development with traditional marketing. Changes in lifestyle and the trend of online shopping are the most important factors that accelerate the development of digital marketing systems. Online shopping and personal shopping clubs are growing rapidly in the world. In addition, this study shows that social media is very important for brand awareness and brand reliability. Pop-ups, e-mail advertisements, search engine ads, website ads and cellphone advertisements are the most important media for personal shopping clubs that tend to attract online buyers. [5]

Next is Escobar, A. Central with research on The Impact of the Digital Revolution in the Development of Market and Communication Strategies for the Luxury Sector. The results of the study explained that the impact of the digital era on the market is substantial and progressive. The real challenge faced by global brands is not about the highest number of their consumers but about the capability to change, to adapt, to innovate, and to understand current trends, fading consumers and potentials so that they can understand the significance of their presence in the market and among consumers. Online strategies must focus on targets that have been set according to the interests and behavior of consumers. This is important to emphasize the difference between real consumers and potential consumers in the luxury goods sector. Classical characteristics and values, the search for new customizations and values as social commitment and sustainability distinguish one consumer from another. [6]

This far, the researchers have not found studies focusing on influencer marketing in the Muslim fashion industry in Indonesia. This study will be one of the preliminary explorations to study influencer marketing in the Muslim fashion industry. This study aims to find the uniqueness and strength of influencer marketing in the Muslim fashion industry in Indonesia, so as to contribute to the development of marketing communication strategies in the Muslim fashion industry in Indonesia.

From the explanation given above, the researchers formulated the research problems as follow:

1. What are the criteria of selecting influencers to promote Muslim fashion in Indonesia?

2. What is the creative process in influencer marketing to promote Muslim fashion?

How effective is influencer marketing in promoting Muslim fashion?

\section{METHOD}

This study on influencer marketing uses case study method, so that the researchers can explore information in depth. For the meaning of a case to be explored, the researchers must be good at sorting out and choosing a case worthy of being a research theme. A case study focuses itself on one particular object chosen as a case to be examined in depth to uncover the reality behind the phenomenon. The case in this study is influencer marketing in the Muslim fashion industry which is a contemporary phenomenon.

According to Yunus [7], describing the object studied in case study research only portrayed itself in depth/in detail/ to obtain a complete picture of the object (wholeness) in the sense that the data collected in the study is studied as a whole, intact and integrated.Data collection technique used are in-depth interviews, documentation, direct observation, and physical artifacts.

The selection of informants is done by purposive sampling technique. Purposive sampling is one of nonrandom sampling techniques where the researchers determine the sampling by establishing specific characteristics that are in line with the research objectives so that they are expected to address research problems. According to Sugiyono [8] purposive sampling is a technique to determine research samples with several considerations that aim to obtain more representative data. There are 6 
informants from different backgrounds in this study that are adjusted to the research interests.

TABLE I. TABLE TYPE STYLES

\begin{tabular}{|c|c|c|}
\hline No & Nama & Keterangan \\
\hline 1 & Andriansyah & $\begin{array}{c}\text { Head Marketing of } \\
\text { PT.HIJUP. COM }\end{array}$ \\
\hline 2 & Heru Susanto & Advertising Agency \\
\hline 3 & $\begin{array}{c}\text { Shafira Sidratul } \\
\text { Muntaha Siswanda }\end{array}$ & $\begin{array}{c}\text { Public Relations of } \\
\text { Hijabers Community }\end{array}$ \\
\hline 4 & $\begin{array}{c}\text { M. Kh. Rachman } \\
\text { Ridhatullah }\end{array}$ & $\begin{array}{c}\text { Marketing, Director of } \\
\text { PT Sygma Media Inovasi } \\
\text { and also Lecturer }\end{array}$ \\
\hline 5 & Demaz Hadi, S.I. Kom & $\begin{array}{c}\text { MICE Manager of } \\
\text { Rabbani - Muslim } \\
\text { Fashion Brand }\end{array}$ \\
\hline 6 & Nadya Tia Silvani & Customer \\
\hline
\end{tabular}

The steps taken in this research are :

1. Selection of Themes, Topics and Cases

2. Literature Review

3. Formulation of Research Focus and Problems

4. Data Collection

5. Data Improvement

6. Data Processing. Once the data is considered perfect, the researchers perform data processing, namely checking the correctness of the data, compiling data, carrying out coding, classifying data, correcting unclear answers to interviews.

7. Data Analysis Process. Essentially, data analysis is done to give meaning to or interpret the data by organizing, compiling, grouping, coding, and categorizing it into segments based on certain categorization in order to obtain findings on proposed research problems.

8. Theoretical Dialogue

9. Triangulation (Confirmability)

10. The Conclusion of Research Findings

11. Research Report [9]

\section{RESULTS}

\section{A. Criteria for Selecting Influencers to Promote Muslim Fashion in Indonesia}

Selecting the influencers for Muslim fashion industry is not an easy matter. Unlike other fashion products in general that are merely the representation of the products, influencers for Muslim fashion industry has greater demand to promote Islam teachings. From the results of the study, the process of selecting influencers is determined based on considerations:

1. Credibility

Credibility can be seen from the level of trust and expertise. People who can be trusted and considered to have insight into brand reliability will be able to convince potential customers to take action.

2. Public Compatibility

Influencers will be a representation of the product they represent. The reason a product chooses an influencer is to support the product to fit the intended customer.

\section{Brand Compatibility}

In choosing influencers, there are considerations taken by companies, such as the suitability of the influencers with the products, the image of influencer, in other words, the suitability of the influencers' values and behaviors with the desired impression and purpose of brands.

4. Attractiveness Quality

Attractiveness in influencers include friendliness, cheerfulness, selling point in terms of physical appearance, having a profession or job that support to purpose of the company.

5. Other considerations

In addition to four reasons given above, a company also considers other factors such as costs incurred, the possibility that influencers will be in trouble, the difficulty or ease of influencers to work together, and how many brands are supported by the influencers. If an influencer promotes too many products, his/her credibility and public fondness will decrease.

As a preliminary step, the company should ask the influencers regarding their follower data. Whether it be age, demography, or viewing duration when it is related to video platform such as YouTube. The image of the influencers should also be taken into consideration. It should suit the image intended by the company. To become a digital influencer, one must meet certain criteria. For example, Instagram influencers can be evaluated from two aspects, which are quantitative and qualitative aspect. Quantitative aspect includes the number of followers, likes in posts and reposts. Qualitative aspect involves content quality and engagement, that is interactions with fellow Instagram users. In addition, comments and responses of the posts should also be taken into consideration.

Important aspects of a digital influencer are Reach, Resonance and Relevance [10]. When an influencer posts something on social media, how many people engage with the post by liking, commenting, sharing, retweeting, clicking links, URLs, or ads, or even filling forms or making purchase. These engagements will occur when digital influencers in question are consistent in establishing communication with their followers and in maintaining their image/reputation related to the products being promoted.

1. Reach refers to the number of followers of digital influencers. However, large number of followers does not guarantee success. The most important thing is to understand which fan category that is suitable with company's target.

2. Resonance is the frequency of followers' engagement with contents shared by influencers. Resonance determines whether the audience will actively forward contents from the influencers and then share them again.

3. Relevance describes the level of suitability and similarity between values adopted by digital influencers and product brand image. Relevance can be in the form of influential content, and whether influencers have the same values, culture and demographics as the brand's target audience. 
To clarify the differences between brand ambassadors and influencer marketing and how influencers are realized in Muslim fashion industry in Indonesia, here is a quote from the interview with Andriyansyah:

"Essentially, a brand ambassador and influencer marketing have similar functions, as the brand awareness of HIJUP and the bridge that connects the brand with the target market. What distinguishes the two is coverage, material and communication methods. For example, Dian Pelangi as the brand ambassador of HIJUP has greater communication coverage than Face of HIJUP. Communication material brought through Dian Pelangi is not limited to hard selling promotion, but leans toward the idea that Dian Pelangi aspires as a Muslim fashion designer and introduces Indonesia to the international world. As an ambassador as well as Dian's exclusive relationship with HIJUP, there should be no E-Commerce and other fashion brands promoted by Dian. Face of HIJUP has different background. It is expected to communicate HIJUP to more specific segment. Face of HIJUP can carry out hard selling and its exclusive relationship is limited to E-Commerce category which means that Face of HIJUP is allowed to promote other fashion brands that are not in HIJUP. In addition to brand ambassadors and Face of HIJUP, we also have regular buzzers every month. However, they are contracted on project basis for shorter duration."

(Interview with Andriyansyah, $19^{\text {th }}$ April, 2018).

On its sixth birthday on August 8, 2017, HIJUP introduced six new faces of HIJUP (The New Face of HIJUP) which became their vision and mission representation, namely Look Good, Feel Good, Do Good in various aspects of life. The New Face of HIJUP has an inspiring role in each field. They are six Indonesian hijaber who are talented in their respective fields. Each of those hijaber has experienced unique hijrah experience including the conveniences gained in undergoing their professions even though they have worn the hijab. These six people represent the characters of HIJUP, they are strong in characters, they are influencers from different communities. Nadiah Faatimah, Gita Savitri, Devi Lia, Karina Mansur, Athieqah Asy-Syahidah, Hamidah Rachmayanti, Ratu Dewi Anandita, and Fatma Sentika.

However, not all Muslim fashion businesspeople are consistent with the products they market, as expressed by Shafira Sidratul Munhata Siswanda: "In backstage, it turned out that she did not wear hijab. She took it off and only wore a tank top. It makes me think why the brand does not hire real Muslim model that positively wears hijab, is tall and slender and is an actual talented model. The brand should choose Muslim brand ambassadors and influencers with good characters and image because they would affect the brand in a positive way. My choice is Laudy Chintya Bella. She is polite and suave which would positively affect the brand image. One of Muslim clothing brands chooses a model that does not actually wear hijab in her everyday life and this diminishes the brand image."

(Interview with Shafira Sidratul Munhata Siswanda, $11^{\text {th }}$ November 2017).

\section{B. Creative Process of Influencer Marketing in Promoting Muslim Fashion}

Creative process is the heart of influencer marketing strategy. From the results of interviews and observations, researchers discovered the fact that

1. For the creative process, companies must make room for influencers to create content according to their creativity.

2. Messages will be effectively received by consumers when they are delivered carrying the characteristics of each influencer. In addition, companies must believe that influencers are the people who know best how to embrace their audiences.

3. In addition to providing space, companies need to ensure that the contents are created to help companies achieve the expected business goals. Companies need to explain the expectations they want to achieve when working with influencers.

4. Companies must provide detailed brief that matches the objectives of the brand marketing campaign to influencers. A clear brief and freedom of creativity will create unique and accurate messages.

5. Creative process is inseparable from content authenticity, honesty, transparency, sense of humour that makes the contents appealing to customers.

6. Similarity attractiveness with consumers

7. Inspiring contents.

As an example of the creative process of HIJUP.COM marketing influencers

Nadiah Faatimah is a mother of one daughter who is active in various cross-field activities, ranging from fashion models, da'wah, and health. Nadia is a lupus survivor who is now active in Indonesian Lupus Foundation and Syamsi Dhuha Foundation as a motivator who continues to pump up the spirit of people with lupus while fostering awareness, insight and support about lupus. The spirit of Nadiah is a reflection of "look good, feel good, do good" that is in line with HIJUP's vision and mission.

An example of a program conducted by one of The New Face of HIJUP is Rumah Quran Al Mukmin Program on $13^{\text {th }}$ November, 2017 in Karawang. PT. HIJUP.COM with Nadiah Faatimah collaborate with Urban Syiar to combat Qur'an illiteracy and earth it.

Another way is done by Rabbani as one of the biggest Muslim fashion companies in Indonesia,

"There are many variances currently since essentially wearing Muslim clothing does not affect comfortability and flexibility in doing activities at various ages, professions, places and times. Some of fashion variants that I observe are monochrome, vintage, sporty, pastel, casual, office look and others. We (Rabbani) collaborated with celebrities who do hijrah and communities to create programs to increase the awareness of Muslim women to wear hijab but are still fashionable and sharia."

(Interview with Demaz, $9^{\text {th }}$ July 2018)

"Creative process must look for relevance and evidence in the form of interaction with consumers. Consumers have the power to choose. They become bridges to communicate with brands. It is better for contents to have history that is 
then shared. There is no such thing as see and buy." (Interview with Heru, $21^{\text {st }}$ February, 2018).

From the consumer side, they have their own expectations on influencers. "Interesting speaking style and review, having similar physical characteristics with me (such as skin color and height). Influencers make beneficial contents that are not just about lifestyle but also about activities that inspire many people including myself."

(Interview with Nadya, 11 June 2018)

\section{Effectiveness of Influencer Marketing in Promoting Muslim Fashion}

From the results of interviews and observations found facts about the benefits of using marketing influencers:

1. Solid outcomes

The results obtained by utilizing influencer marketing have a ratio of roughly 1:5. Influencer marketing is the right strategy to get new customers, even more effective than email marketing and organic methods.

2. Building trust

The use of influencer marketing on social media can make Muslim fashion industry more credible. Influencers use the same products as the target market and they can show the business value through photos or videos they make as testimonies. Followers of influencer marketing invited by the company to collaborate can gain new perspective about the brand. By seeing quality products used by their idols, the brand can become a reference product for the target market.

3. Reaching expected target audience

By choosing influencer marketing whose topics are relevant to the brand, the brand automatically targets the target audience that matches the brand, who will then follow the influencers because they like the content given. This could be a win-win solution, since the brand does not spend energy and resources to reach the audience with the most suitable persona. Companies can see first-hand the interaction with brands through comments left on posts made by influencers.

4. Determining where the target should be directed Marketing influencers are different on every platform, so that they can target the market on different platform accurately. The most effective platforms now are Facebook, YouTube, Instagram and Twitter.

Companies must choose the most appropriate platform to promote their brands and represent company business properly.

A person appointed as an influencer is chosen based on his expertise, popularity and reputation. By employing marketing influencers, companies (brands) will more loyal to the influencers by establishing profound relationship which does not merely endorse but also share information and privilege for new products as well as behind-the-scene process of the brand. [11]

Furthermore, the people appointed as influencers are tasked with influencing the decisions of their immediate environment (friends, family, and followers) to get to know a brand that is marketed through content created by themselves or by brands in posts on various personal social media platforms owned by these influencers which ultimately leads to the sale of the brand being marketed. Consumer opinions about the effectiveness of marketing influencers, "The advantage is to increase consumer trust and interest in products by increasing product appeal through influencers."

"Yes, people would be tempted because it is appealing, especially when the influencers are considered as trendsetter. However, in the end it all depends on the products since a product that looks good on other people does not always look good on ourselves." (Interview with Nadya, 11 June 2018)

\section{DISCUSSION}

Today's business world is experiencing 3 major changes that are very influential on the form of business competition that occurs.

1. Communication media revolution. This really changes the format of how people make business decisions, buy products, consider, then they can choose products that are consumed daily. Because of this communication media revolution, especially internet-based one or social media, the basis of consumer decision making becomes something that is hard to guess. [12]

2. Changes that occur in our society from an economic perspective. There is an increasing trend of nouveau riche or OKB (Orang Kaya Baru), or Middle Class Economy in business terms. What happens then when the society enters $\mathrm{OKB}$ or Middle Class Economy class? They have more money, their behaviours changes. And that is what makes them have different needs, different desires, and different expectations toward everything they want or need in their lives.

3. Business maps change very dramatically due to disruption conditions. What we are talking about is how hard it is now to predict something linearly since everything changes rapidly. For people who cannot predict, the symptoms are hard to see, and they collapse in the blink of an eye. For example, in transportation business, a dominant company in the market of taxi panicked in the face of online transportation.

(Interview with Rachman Ridhatullah, 24 ${ }^{\text {th }}$ July 2018)

The three changes have influenced the fashion industry in Indonesia, including its promotional activities.

According to Chris Heuer in Solis [13], there is $4 \mathrm{C}$ in employing influencer marketing in social media:

1. Context is how a person frames a story through the use of language and message content. This could be in the form of graphics, colours, and interesting design.

2. Communication is the way to communicate and share that makes people comfortable to listen, response, share messages to public.

3. Collaboration is cooperation between the giver and recipient of the message, the account and the followers, so that the message is communicated efficiently and effectively.

4. Connection is the way to establish sustainable relationship. 
In determining influencers, the company adjusts to its target and business scope. Here are the types of influencers [14]:

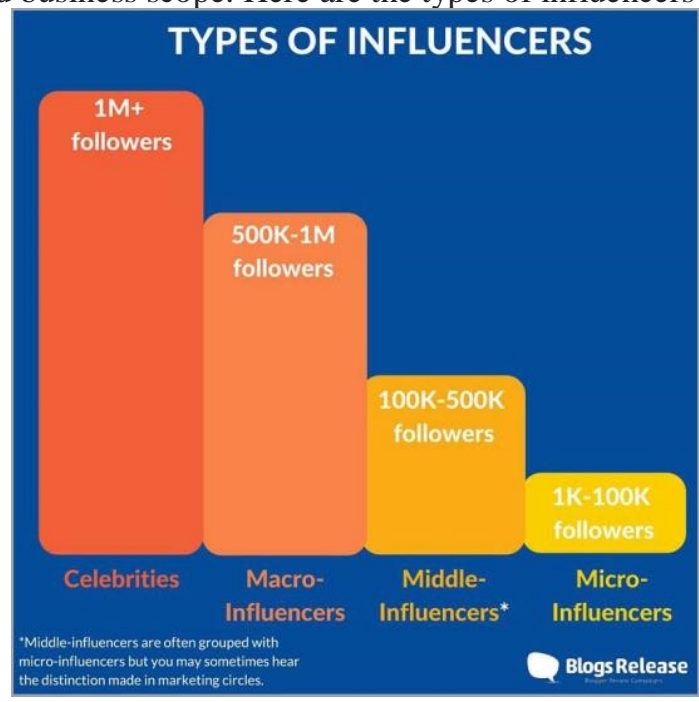

Fig. 1 Type of Influencer

Digital influencers are one of the main actors to make messages viral. Share, tags and hashtags features, as well as Instastory are tools that are used so that messages can spread quickly. Unlike massive, disperse but conventional advertising, promotion through influencers is more targeted because the profile of the influencers and their followers can be adjusted to the target audience of the product, re-shared, and tagged with more or less similar population characteristics. Other things that make Instagram digital influencers important is the high tech and high touch quality. [15] High tech quality refers to the technology that enables digital communication. High touch refers to emotional and relational aspects that occur between the influencers and their followers. Influencers are those who are considered credible, trustworthy and easily accessible due to interactions (comments and responses), things that are noticeably absent from conventional advertising method. In choosing digital influencers, value compatibility between the influencers and the followers and public trust in the influencers are important factors to be taken into considerations.

\section{CONCLUSION}

Muslim fashion industry in Indonesia using influencer marketing in promoting their products is more than just keeping up with the trend. Muslim fashion businesspeople understand well and follow influencer marketing professionally just as any other business sectors. Influencer marketing in this industry has values and objectives that are well worked out. Influencers employed in Muslim fashion industry possess unique characteristics with distinct profession background. The use of influencers in the marketing of Muslim fashion becomes more complex because in addition to product promotion, influencers are tasked with inspiring Muslims to be better and adhere to Islamic teachings, creating Islamic beautiful branding which in turn requires high level of trust. It is not uncommon for consumers to identify themselves with the influencers. In this context, it can be concluded that high touch aspect is more dominant.

We suggest that Muslim fashion businesspeople in Indonesia should conduct researches or fact finding process to determine influencers that fit company's goals and values. However, bear in mind that influencer marketing is not the only shortcut to improve marketing.

\section{ACKNOWLEDGMENT}

This research is supported or partially supported by Indonesian Endowment Fund for Education (Lembaga Pengelola Dana Pendidikan - LPDP RI) as one of the funding agencies and credible scholarship in Indonesia.

\section{REFERENCES}

[1] Tjiptono, Fandy, Strategi Pemasaran Edisi 4, Yogyakarta : Andi, 2015.

[2][3] Lee, Monle \& Carla Johnson, Prinsip-prinsip Periklanan Dalam Perspektif Global, Jakarta : Kencana Predana Media Group, 2010

[4] Tjiptono, Fandy, Chandra, Gregorius, Pemasaran Global Konteks Offline \& Online, Yogyakarta : UPP STIM YKPN, 2012.

[5] Nazlim Tüzel Uraltaş, New Digital Marketing Actors : Private Shopping Clubs And Their Advertising Practices, Journal of Media Critiques (JMC) P-ISSN: 2056-9785 E-ISSN: 2056 9793, 2014, p 1326

[6] Escobar, A, The Impact Of The Digital Revolution In The Development Of Market And Communication Strategies For The Luxury Sector (Fashion Luxury), Central Europian Business Review Vol 5 Number 2' 2016, p 17-36

[7] Yunus, Hadi Sabari, Metode Penelitian Wilayah Kontemporer, Yogyakarta : Pustaka Pelajar. 2010.

[8] Sugiyono, Metode Penelitian Kuantitatif Kualitatif dan RD, Bandung: Alfabeta, 2012

[9] Rahardjo, Mudjia, Studi Kasus Dalam Penelitian Kualitatif : Konsep dan Prosedurnya, Malang : Universitas Islam Negeri Maulana Malik Ibrahim, 2017.

[11] Swastha, Basu, Manajemen Pemasaran Modern. Yogyakarta : Liberty, 2000.

[12] Bungin, Burhan, Konstruksi Sosial Media Massa : Kekuatan Pengaruh Media Massa, Iklan Televisi dan Keputusan Konsumen serta Kritik Terhadap Peter L. Berger dan Thomas Luckmann, Jakarta: Kencana, 2008.

[10][13] Solis, Brian, The Rise of Digital Influence, https://techcrunch.com/2012/03/21/klout-kred-peerindex-radian6/, Accessed on June 10, 2018 at 11.00 PM.

[14] https://www.ecwid.com/id/blog/how-to-use-micro-influencers-on instagram-to-boost-e-commerce-sales.html, Accessed on July 19, 2018 at $02.30 \mathrm{PM}$

[15]Andrew F. Wood dan Matthew J. Smith, Online Communication: Linking Technology, Identity and Culture, New Jersey: Lawrence Erlbaum Associates, Inc , 2005. 